\title{
Impacts of Land Abandonment on Vegetation: Successional Pathways in European Habitats
}

\author{
Bernard Prévosto • Loek Kuiters • Markus Bernhardt-Römermann • \\ Michaela Dölle • Wolfgang Schmidt • Maurice Hoffmann • Jan Van Uytvanck • \\ Andreas Bohner • Daniel Kreiner • Jutta Stadler • Stephan Klotz • \\ Roland Brandl
}

(C) The Author(s) 2011. This article is published with open access at Springerlink.com

\begin{abstract}
Changes in traditional agricultural systems in Europe in recent decades have led to widespread abandonment and colonization of various habitats by shrubs and trees. We combined several vegetation databases to test whether patterns of changes in plant diversity after land abandonment in different habitats followed similar pathways. The impacts of land abandonment and subsequent woody colonization on vegetation composition and plant traits were studied in five semi-natural open habitats and two arable habitats in six regions of Europe. For each habitat, vegetation surveys were
\end{abstract}

Electronic supplementary material The online version of this article (doi:10.1007/s12224-010-9096-z) contains supplementary material, which is available to authorized users.

B. Prévosto $(\bowtie)$

Cemagref, EMAX, 3275 route Cézanne, CS 40061, 13182 Aix-en-Provence cedex 5, France

e-mail: bernard.prevosto@cemagref.fr

L. Kuiters

Alterra, Centre for Ecosystem Studies, Wageningen UR, P.O. Box 47, NL-6700 AA Wageningen,

The Netherlands

e-mail: loek.kuiters@wur.nl

M. Bernhardt-Römermann • M. Dölle $\cdot$ W. Schmidt

Faculty of Forest Sciences and Forest Ecology,

Department Silviculture and Forest Ecology of the Temperate Zones,

Georg-August University Göttingen, Buesgenweg 1, 37077 Goettingen, Germany

M. Bernhardt-Römermann

e-mail: Markus.Bernhardt@forst.uni-goettingen.de

M. Dölle

e-mail: mdoelle@gwdg.de

W. Schmidt

e-mail: wschmid1@gwdg.de

M. Hoffmann · J. Van Uytvanck

Department Ecosystems, INBO Research Institute for Nature and Forest, Kliniekstraat 25,

BE-1070 Brussels, Belgium 
carried out in different stages of succession using either permanent or non-permanent plots. Consecutive stages of succession were defined on a physiognomic basis from initial open stages to late woody stages. Changes in vegetation composition, species richness, numbers of species on Red Lists, plant strategy types, Ellenberg indicator values of the vegetation, Grime CSR strategy types and seven ecological traits were assessed for each stage of the successional pathway. Abandonment of agro-pastoral land-use and subsequent woody colonization were associated with changes in floristic composition. Plant richness varied according to the different habitats and stages of succession, but semi-natural habitats differed from arable fields in several ecological traits and vegetation responses. Nevertheless, succession occurred along broadly predictable pathways. Vegetation in abandoned arable fields was characterized by a decreasing importance of R-strategists, annuals, seed plants with overwintering green leaves, insect-pollinated plants with hemi-rosette morphology and plants thriving in nutrient-rich conditions, but an increase in species considered as endangered according to the Red Lists. Conversely, changes in plant traits with succession within the initiallyopen semi-natural habitats showed an increase in plants thriving in nutrient-rich conditions, stress-tolerant plants and plants with sexual and vegetative reproduction, but a sharp decrease in protected species. In conclusion, our study showed a set of similarities in responses of the vegetation in plant traits after land abandonment, but we also highlighted differences between arable fields and semi-natural habitats, emphasizing the importance of land-use legacy.

Keywords Arable field · Natural forest regeneration · Secondary succession · Semi-natural habitat

Plant nomenclature Jäger and Werner (2002)

\author{
M. Hoffmann \\ e-mail: maurice.hoffmann@inbo.be \\ J. Van Uytvanck \\ e-mail: jan.vanuytvanck@inbo.be
}

\title{
A. Bohner
}

HBLFA Raumberg-Gumpenstein, Altirdning 11, 8952 Irdning, Austria

e-mail: andreas.bohner@raumberg-gumpenstein.at

D. Kreiner

Nationalpark Gesäuse GmbH, 8913 Weng im Gesäuse 2, Austria

e-mail: daniel.kreiner@nationalpark.co.at

\section{J. Stadler $\cdot$ S. Klotz}

Department of Community Ecology, UFZ Leipzig-Halle, Theodor-Lieser-Str. 4, 06120 Halle (Saale), Germany

\section{J. Stadler}

e-mail: jutta.stadler@ufz.de

\section{R. Brandl}

Department of Ecology/Animal Ecology, Philipps-Universität Marburg, Faculty of Biology,

Karl-von-Frisch-Str.8, 35032 Marburg, Germany

e-mail: brandlr@staff.uni-marburg.de 


\section{Introduction}

Changes in land use over recent decades have influenced habitat and vegetation composition in most regions of Europe (Poschlod et al. 2005; Stoate et al. 2009). After World War II, agriculture intensified in productive areas whereas areas that did not allow mechanized agricultural techniques were abandoned. The most obvious effect of this land abandonment was the colonization of previously open landscapes by trees and shrubs, which were often of high biological and aesthetic value and considerable recreational potential (Young et al. 2005). Thereby, the role of these areas as reservoirs of biodiversity changed. Many plant species restricted to habitats such as grassland, meadow, heathland or dune grassland are dependent on traditional land-use disturbance regimes (Gustavsson et al. 2007; Römermann et al. 2009). The management regime governing these semi-natural habitats is a major factor that affects the reproductive success of single plant species and whole vegetation patterns (Bakker 1989). Different management regimes create particular disturbance regimes in space and time, which in turn provide conditions for a particular set of plant species with a particular set of interactions between species (Bakker 1989; Pykäla 2000). The different management regimes thus represent key drivers for biodiversity in agricultural landscapes (Poschlod et al. 2005).

Abandonment of traditional management can lead to a decrease in species richness by changing habitat conditions and competitive regime within the assemblage of plant species (Grubb 1977; Huston 1979; Bignall and McCracken 1996; Provoost et al. 2004; Dölle et al. 2008; Römermann et al. 2009). However, most studies on the impact of land abandonment on species diversity have focused on a single type of vegetation, stage of succession or region, making it difficult to compare results. Taking the example of grasslands, several studies found a decrease in species diversity with landuse abandonment (e.g., Smith and Rushton 1994; Pettit et al. 1995) while others found the effects, if any, were only minor (e.g., Bossuyt et al. 2006; Peco et al. 2006). Obviously, plant diversity can be more strongly affected by other factors, such as the biogeographic species pool, land-use history, type of management or processes like bush encroachment (e.g., Gustavsson et al. 2007; Stadler et al. 2007).

Species identity differs between regions and/or habitats, making it difficult to run cross-comparisons between studies. Functional traits of plant species offer a way to compare studies even across biogeographic realms. Plant traits are linked to plant function and provide insight into the key processes driving vegetation changes (Lavorel and Garnier 2002; Lavorel et al. 2007).

Our study combined several large databases on vegetation succession after abandonment in various European habitats submitted to traditional agricultural practices: calcareous grassland and heathland (the Netherlands), coastal dune grassland (Belgium), mid-elevation grassland (central France), alpine pasture (Austrian Alps) mainly submitted to grazing, and arable fields annually ploughed (Germany). Successions considered in our study were characterized by former agropastoral land use, either intensive (arable fields) or extensive (semi-natural habitats). Land abandonment occurred in the past decades and led to a succession towards natural vegetation. Overall, our study addressed the following questions:

i) What are the main changes in the dynamics, composition and richness of plant community assemblies after abandonment? 
ii) Based on functional traits, do post-abandonment plant communities assemble along a broadly repeatable successional pathway or exhibit different pathways (Cramer et al. 2008; Bernhardt-Römermann et al. 2008)?

iii) If so, what are the plant trait changes shared by all types of habitats, and what are those mainly determined by prior land use?

\section{Material and Methods}

\section{Database}

Our study is based on vegetation surveys performed in six different regions across Europe (Table 1 and Electronic Supplementary Material 1 for sites description). The habitats used for the surveys can be split into semi-natural habitats with a long history of agro-pastoral land use (grassland, heathland), and arable fields. These habitats were traditionally used for crops (arable fields), grazing only or in combination with mowing and sod-cutting (grassland, heathland).

In each of these habitats, vegetation surveys were carried out using either permanent plots (arable fields, alpine grassland) or non-permanent plots (other habitats; Table 1). For each survey, we distinguished stages of succession describing the plant community succession after abandonment of the management regime. We defined four stages of succession according to the dominant life forms, grasses, shrubs and trees:

I. Initial stage, referring to the community present under traditional land use.

II. Grass stage, dominated by graminoid species with tree or shrub cover $<30 \%$.

III. Scrub stage, dominated by woody phanerophytes 0.5 to $5 \mathrm{~m}$ tall, with cover $>30 \%$ and tree cover remaining below $30 \%$.

IV. Woodland stage, dominated by trees at least $5 \mathrm{~m}$ tall and covering at least $30 \%$ of the surface area.

The number of stages of succession for each survey varied between 2 and 4, reflecting the difference in the initial community composition, propagule pressures, site conditions and time elapsed since abandonment.

\section{Analysis of Vegetation Composition}

Plot size differed between surveys (Table 1). Furthermore, vascular plants were recorded in each plot and abundance-dominance was estimated by eye using various scales.

Previous studies had repeatedly shown that analyses of plant traits or indicator values weighted by abundance showed little difference from studies using simple presenceabsence data (Schaffers and Sýkora 2000; Dzwonko 2001, but see Cingolani et al. 2007). We therefore recoded all cover-abundance data to presence/absence to enable our analyses to minimize the impact of methodological differences among studies.

Changes in plant composition from stage (I) to a later stage were analyzed as follows:

1. We selected the species we recorded in more than $5 \%$ of the relevés belonging to a particular stage of each survey. This threshold was chosen to exclude rare species. 


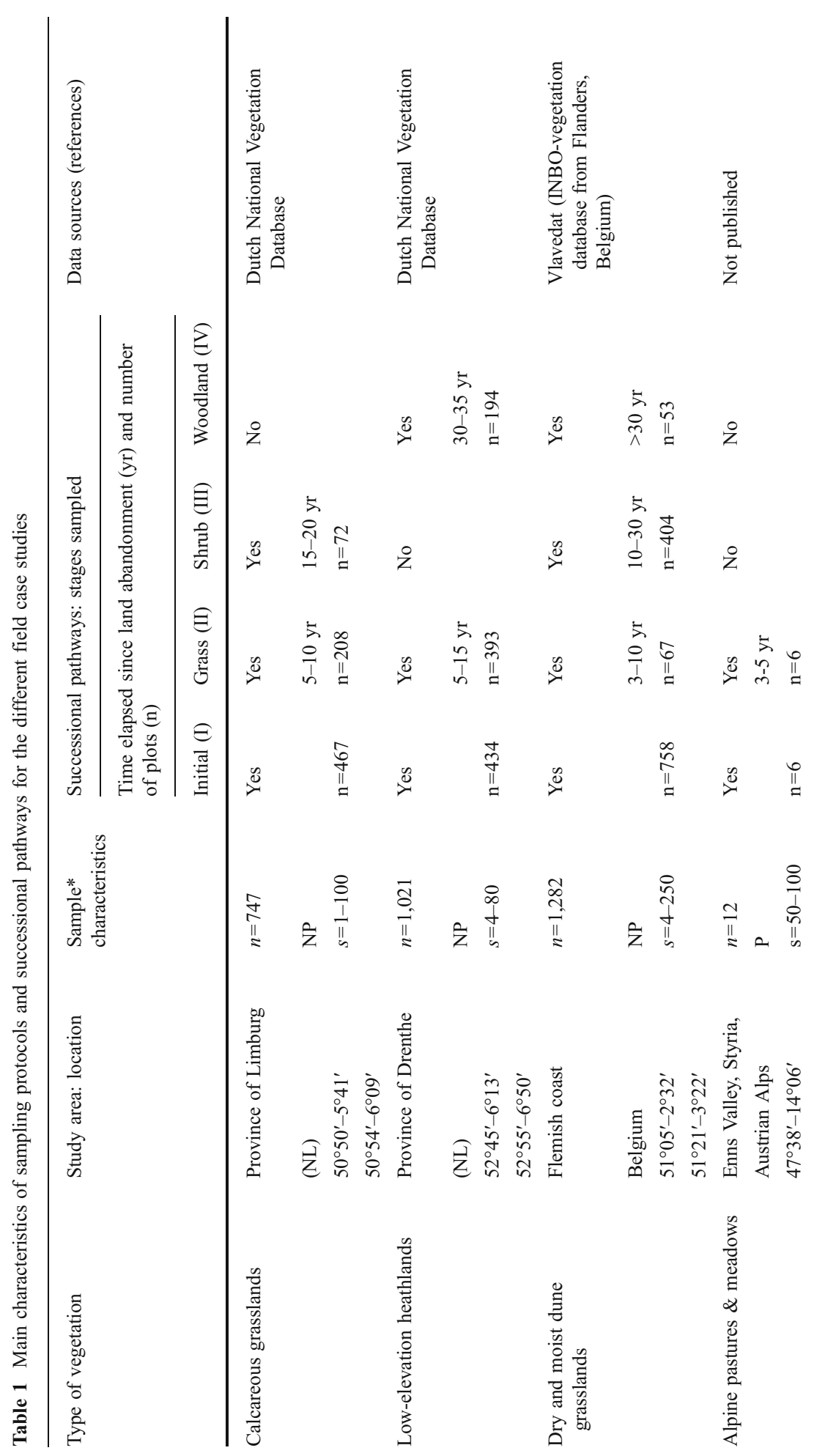


B. Prévosto et al.

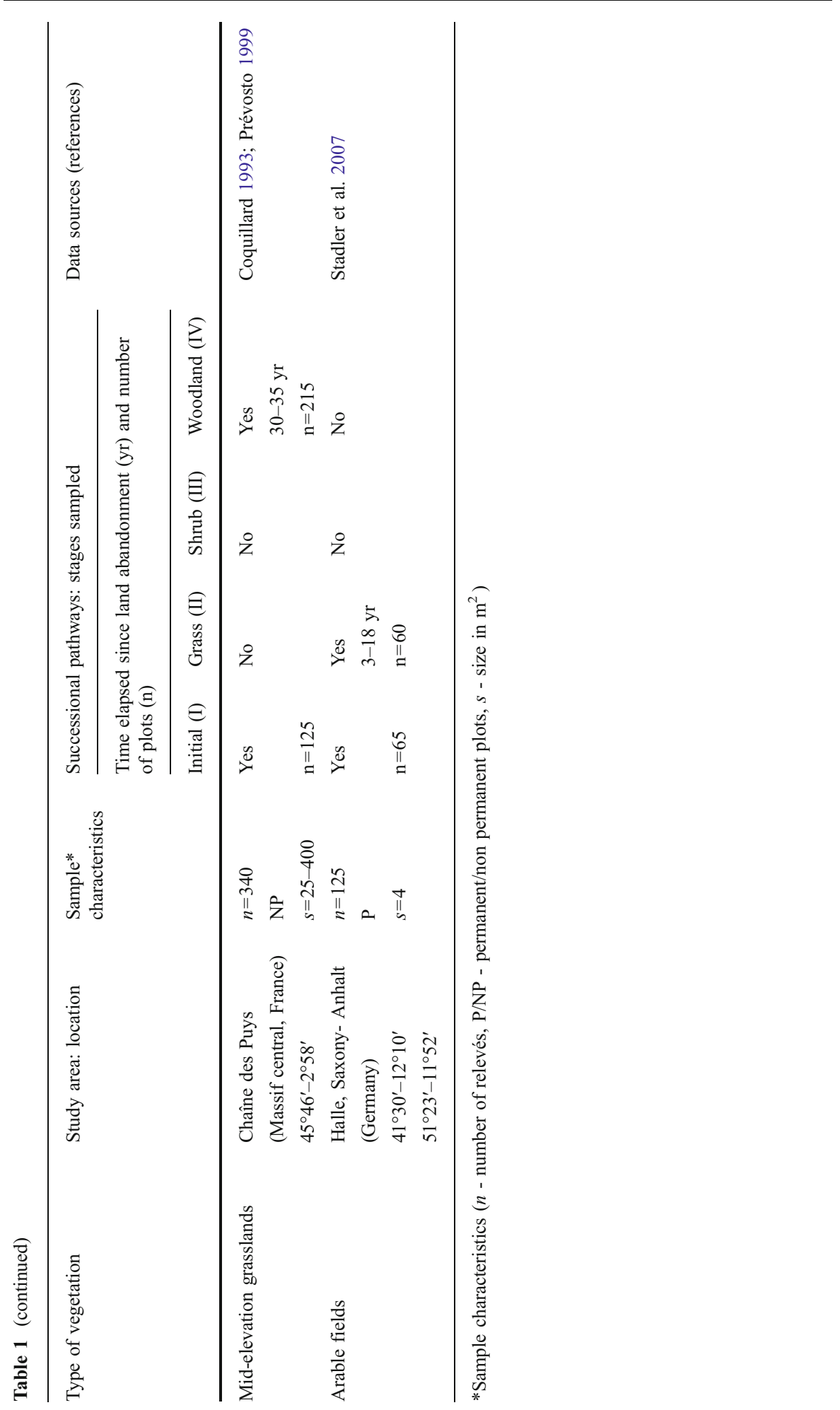


2. We compared with species present in the relevés of the following stage and identified each species according to the following criteria:

a) 'Extinct': species whose numbers had fallen to $<1 \%$.

b) 'Loser': species whose numbers had fallen by $>40 \%$.

c) 'Stable': species whose numbers had risen or fallen by $<40 \%$.

d) 'Winner': species whose numbers had risen by $>40 \%$.

e) 'Newcomer': species initially absent, now in numbers $>5 \%$.

Furthermore, we included the conservation status of species in our analyses using Red Lists (when available). We counted all species of the different stages for each vegetation survey considered as 'critically endangered', 'endangered', 'vulnerable' or 'nearly threatened'. References for the Red Lists used are as follows: for Belgium, Biesbrouck et al. (2001); for Germany, Garve (2004); for Austria, Niklfeld and Schratt-Ehrendorfer (1999); for The Netherlands, van der Meijden et al. (2000); for France, Olivier et al. (1995).

\section{Functional Traits}

For comparison across study sites, we used the CSR plant strategy types according to Grime (1977). We used a simple method to rank these strategy types on a linear scale derived from Hill et al. (2002) in three dimensions, using the following convention:

\begin{tabular}{ll}
\hline $\mathrm{C}$ (competitor) & $=(1,0,0) ;$ \\
$\mathrm{S}$ (stress tolerator) & $=(0,1,0) ;$ \\
$\mathrm{R}$ (ruderal) & $=(0,0,1) ;$ \\
SR $($ stress-tolerant ruderal $)=(\mathrm{S}+\mathrm{R}) / 2$ & $=(0,0.5,0.5) ;$ \\
$\mathrm{CSR}($ completely intermediate $)=(\mathrm{C}+\mathrm{S}+\mathrm{R}) / 3$ & $=(0.33,0.33,0.33)$
\end{tabular}

Average C, S and R values were then computed for each relevé. Grime's strategy type was extracted from the BIOLFLOR Database (Klotz et al. 2002).

Ellenberg values (Ellenberg et al. 2001) are well established as surrogates for changes in environmental factors associated with plant communities (e.g., Persson 1980; van der Maarel 1993, Dzwonko and Loster 1997). Available Ellenberg indicator values for light availability $(L)$, soil reaction $(R)$, nitrogen availability $(N)$ and soil moisture $(F)$ for plants in every relevé were used to calculate the average indicator value of each relevé (sum of indicator values of species present in the relevé divided by the number of species for which an indicator value was available). Furthermore, we included seven plant traits extracted from the BIOLFLOR Database:

1. Raunkiaer life form, with five categories: chamaephyte, geophyte, hemicryptophyte, phanerophyte $=$ (macrophanerophyte + nanophanerophyte), therophyte.

2. Type of reproduction, with four categories: 's' by seed/spore; 'ssv' mostly by seed and rarely vegetative, 'sv' by seed and vegetative, 'vvs' mostly vegetative, rarely by seed.

3. Vegetative propagation, with four categories: 'runner': lateral shoot with long thin internodes and adventitious roots; 'rhizome': subterranean or close to the 
soil surface, mostly thickened shoot with short internodes, adventitious roots and cataphyllary leaves; 'root-shoot': adventitiously-rooted shoot growing from a main or lateral shoot; 'miscellaneous' for all other types.

4. Leaf anatomy, with three categories: 'scleromorphic': firm, stiff leaves with thickened epidermis and cuticula, but with mechanisms promoting water transport under beneficial conditions; 'mesomorphic': between scleromorphic and hygromorphic; and 'hygromorphic': delicate shade and semi-shade plants.

5. Leaf persistence, with four categories: ' $v$ ': spring green; ' $s$ ': summer green; ' $w$ ': overwintering green; and ' $i$ ': persistent green.

6. Plant morphology, with three categories: 'erosulate': development of long internodes, leaves spaced at roughly equal intervals on the axes; 'hemi-rosette': single or repeated change between phases in which either long or short internodes develop, leaves either scattered or tightly packed at the shoot; and 'rosette': leafy shoots exclusively consisting of short internodes with all foliar leaves basally arranged to form a rosette.

7. Type of pollination, with three categories: 'wi': by wind; 'in': by insects; 'self': different types of self-pollination; 'div': other types of pollination.

Each species of each presence/absence-transformed relevé was assigned one of the trait categories. Frequency of each trait category was then computed per relevé across species. In a second step, the mean of the frequencies of all the relevés included in the given stages was calculated.

\section{Statistical Analysis}

To characterize the general pattern of vegetation dynamics occurring during succession, we used principal components analysis (PCA) employing the correlation matrix. PCA was performed on a data matrix composed of values for each trait category values (31 categories) recorded in the different stages of each site (altogether 21 stages). Calculations were run on ADE-4 software (Thioulouse et al. 1997). The pathway for a given site during succession was then assessed by drawing the pathway within the two-dimensional space from stage to stage.

In addition, comparisons among stages of a given habitat for species richness, mean Ellenberg and Grime values, and ecological trait values were evaluated using ANOVAs followed by a multiple range test (Tukey test). Before each analysis, variance normality and homogeneity were checked, and when these conditions were not met, transformations were applied to approach the ANOVA assumptions. Otherwise, we used non-parametric Kruskall-Wallis tests.

\section{Results}

\section{Species Richness and Composition}

Species richness (= mean number of species per plot) did not show a consistent pattern of variation with succession (Fig. 1a). Species richness decreased for calcareous grasslands, alpine grasslands and in one case of arable fields (arable field 
Fig. 1 a Mean number of species per plot for the different stages of succession. For a given habitat, different lowercase letters indicate statistical differences among stages $(P<0.05)$. Bars indicate standard deviations. b Vegetation changes in transition phases (noted I/II, I/III or I/IV) from initial stage I to subsequent stages of succession: II (grass stage), III (scrub stage) or IV (woodland stage) for the different habitats

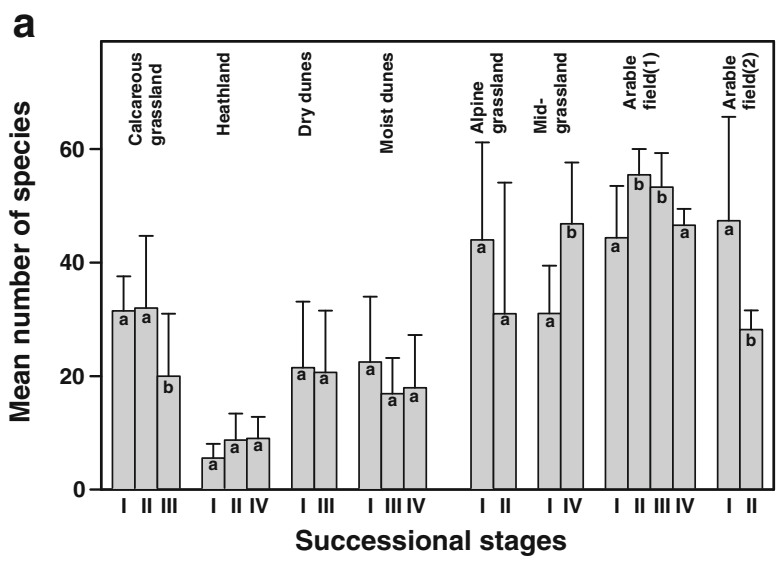

b

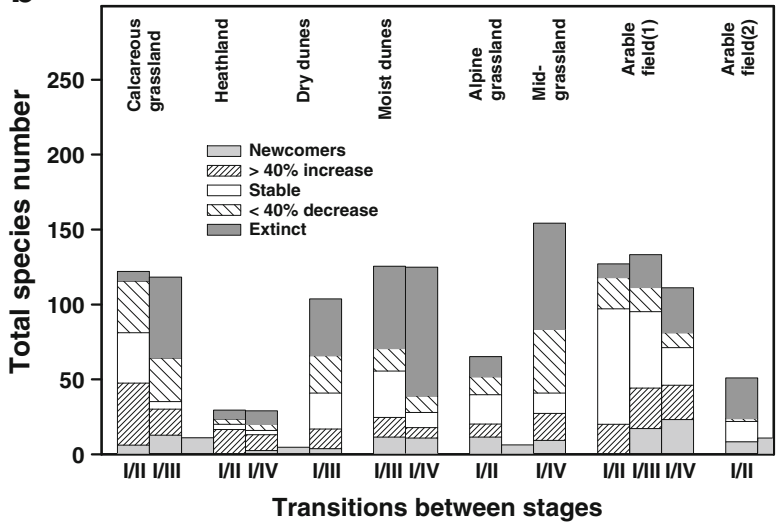

(2)) but increased for heathlands and mid-elevation grasslands. We found a humpshaped relationship for arable fields (1) and no change in species richness in coastal dune grasslands. Floristic composition was more strongly affected by the transition to later stages of succession (Fig. 1b): the total number of 'stable' species per stage decreased with succession, while the proportion of other categories increased, and major shifts in plant composition occurred with shrub or tree colonization.

\section{Species of the Red Lists}

The total number of species on the Red Lists differed between semi-natural habitats and arable fields (Fig. 2). Semi-natural habitats showed a decrease due to disappearance of species dependent on open conditions and management regime, such as Cirsium acaule, Briza media, Gentianella germanica (calcareous grasslands), Drosera rotundifolia, Andromeda polifolia, Eriophorum vaginatum (moist heathlands), Nardus stricta, Trichophorum cespitosum (dry heathlands), Blackstonia perfiolata, Gentianella amarella, Herminium monorchis (moist dunes), Koeleria macrantha, Thesium humifusum (dry dunes). In contrast, arable fields showed a moderate increase followed by a decrease in arable fields (1). For instance, Silene noctiflora or Euphrasia 
Fig. 2 Total number of species of the stages of succession appearing on Red Lists in the different habitats

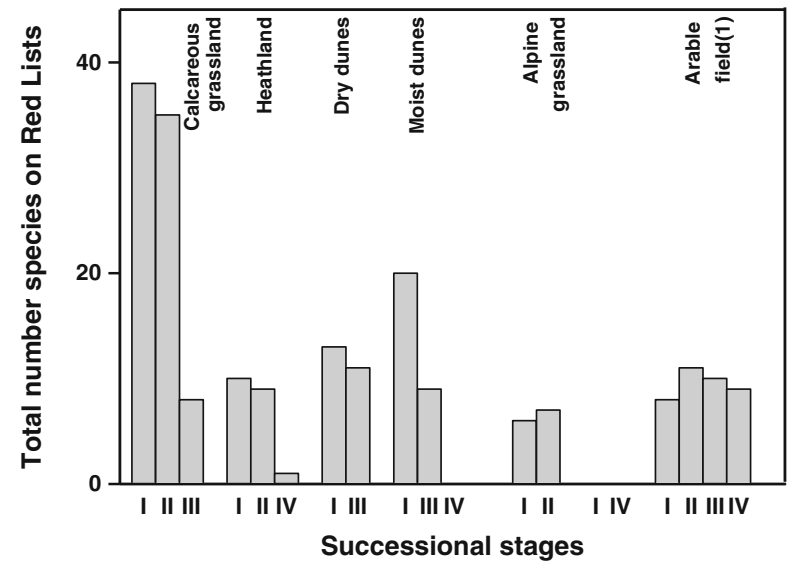

officinalis were found in the first stages but disappeared in the last stage of the succession, whereas species such as Tanacetum corymbosum predominantly growing at forest edges or in gaps was a newcomer in the second stage and remained stable throughout the succession. No species of the Red List were encountered in the midelevation grasslands of the French Massif Central, despite high species richness.

\section{Functional Traits}

\section{Ellenberg Indicator Values}

Ellenberg values for light decreased with succession at all sites (Fig. 3). Ellenberg values for nitrogen displayed contrasting responses between semi-natural habitats where values increased during succession, and arable fields where values decreased (arable field (1)) or remained unchanged (arable field (2)). Ellenberg indicators for soil reaction clearly decreased in calcareous grasslands and arable fields (1) but increased or remained stable in other habitats. Responses of Ellenberg values for soil moisture increased with succession in calcareous grasslands, dry coastal dunes grasslands and mid-elevation grasslands, but decreased or remained stable in the other habitats.

\section{Grime CSR Strategy Types}

Plant strategies according to Grime's classification differed largely through stages of succession, but showed a consistent response among the different habitats (Fig. 4). The competitors, which concerned more than half of the species of the early stages of succession, increased significantly with succession (except in alpine grasslands, not significant), whereas the ruderals declined with succession and the stress tolerators decreased only in semi-natural habitats.

\section{Other Traits}

Hemicryptophytes decreased with succession in semi-natural habitats, while phanerophytes logically increased in all habitats (Table 2). Therophytes, which are 
Fig. 3 Average Ellenberg indicator values according to the stages of succession for light, nitrogen, soil reaction and soil moisture (mean+s.d.). For a given habitat, different lowercase letters indicate statistical differences between the stages $(P<0.05)$
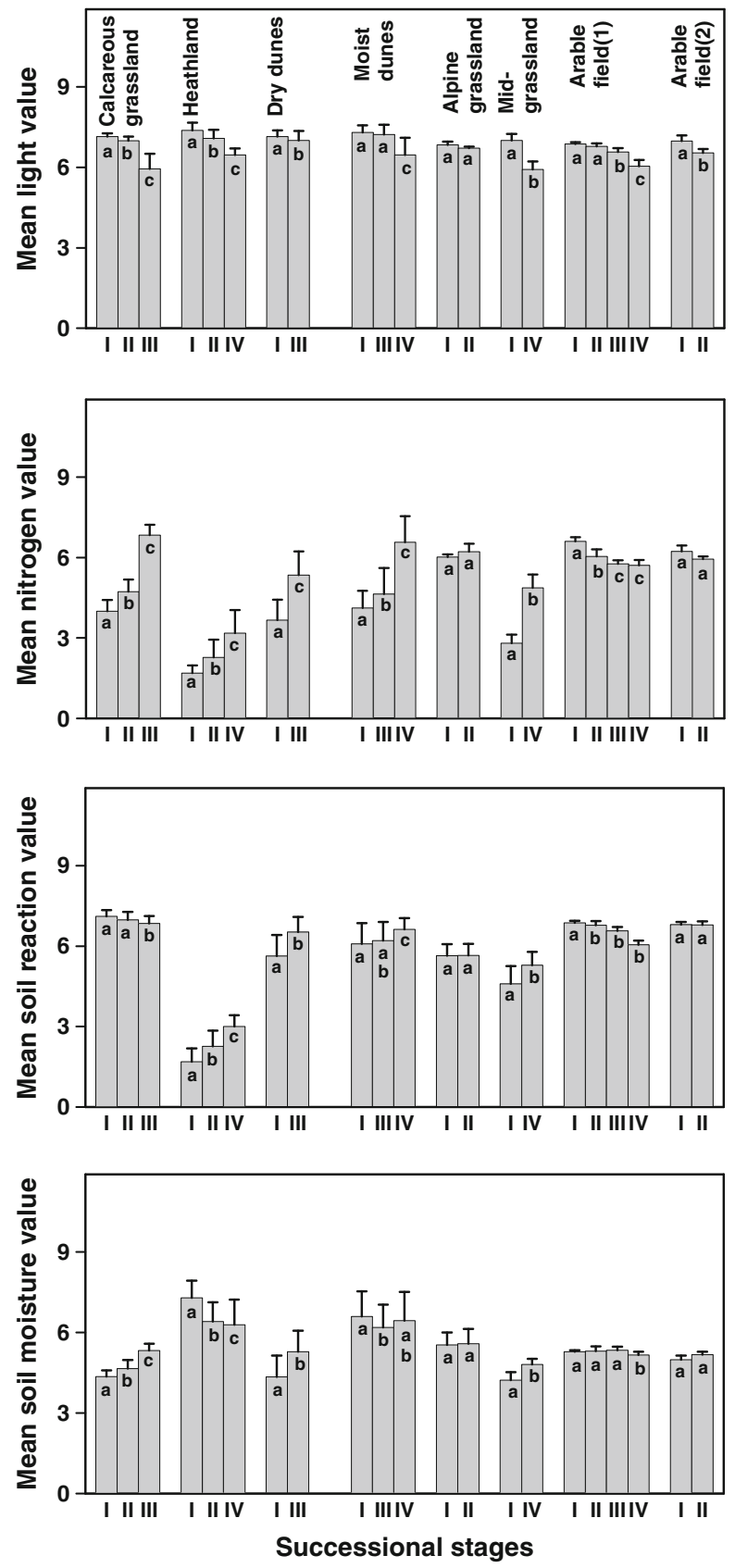

rare in semi-natural habitats, were common in the initial stages of arable lands, but fell sharply after land abandonment. Plants reproducing only by seeds increased with succession in semi-natural habitats but decreased in arable fields. Responses of the other reproduction groups were more variable. Vegetative propagation by lateral 
Fig. 4 Plant strategies according to Grime's classification. We present average plot values for competitiveness (C), stresstolerance (S) and ruderal type (R) for the different stages of succession. For a given habitat, different lowercase letters indicate statistical differences among stages $(P<0.05)$. Bars indicate standard deviations
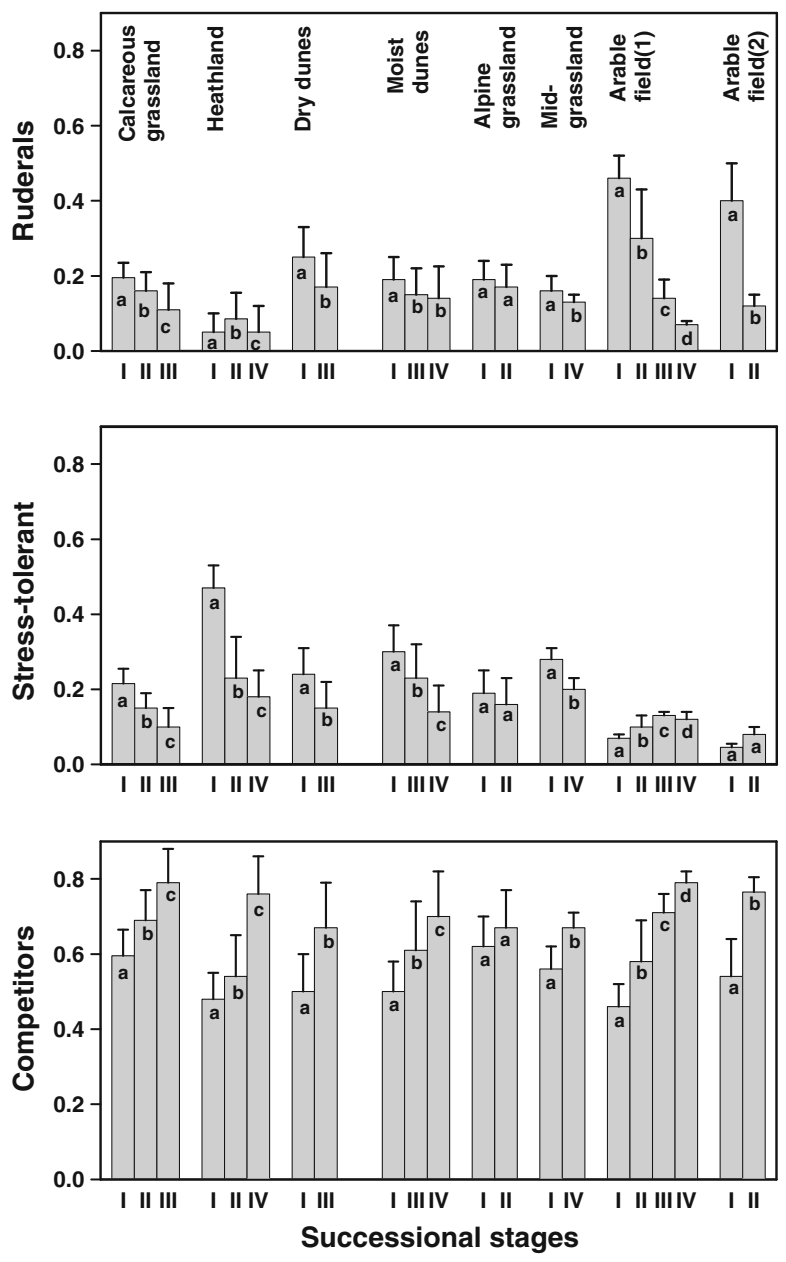

shoots with long thin internodes (runners) declined or remained stable with succession in semi-natural habitats, but increased in arable fields. Propagation by rhizomes was more common in semi-natural habitats, whereas root-shoot propagation became more frequent as succession progressed in all habitats. Mesomorphic leaf anatomy was clearly dominant in all the habitats and generally increased with succession (except for calcareous grasslands), whereas scleromorphic anatomy showed the opposite pattern. Hygromorphic leaf anatomy was of minor importance in initial stages but its importance increased in semi-natural habitats (calcareous grasslands), while it remained stable in arable fields. The relative number of species with persistent leaves decreased with succession in semi-natural habitats, whereas they peaked in intermediate stages in arable fields. Species with summer green leaves increased significantly in every habitat. In all the habitats, semi-basal species decreased with succession whereas basal leaf species decreased only in semi-natural habitats. Relative numbers of erosulate species increased with succession, sometimes remarkably, except in arable fields (1). The proportion of plants pollinated by wind 


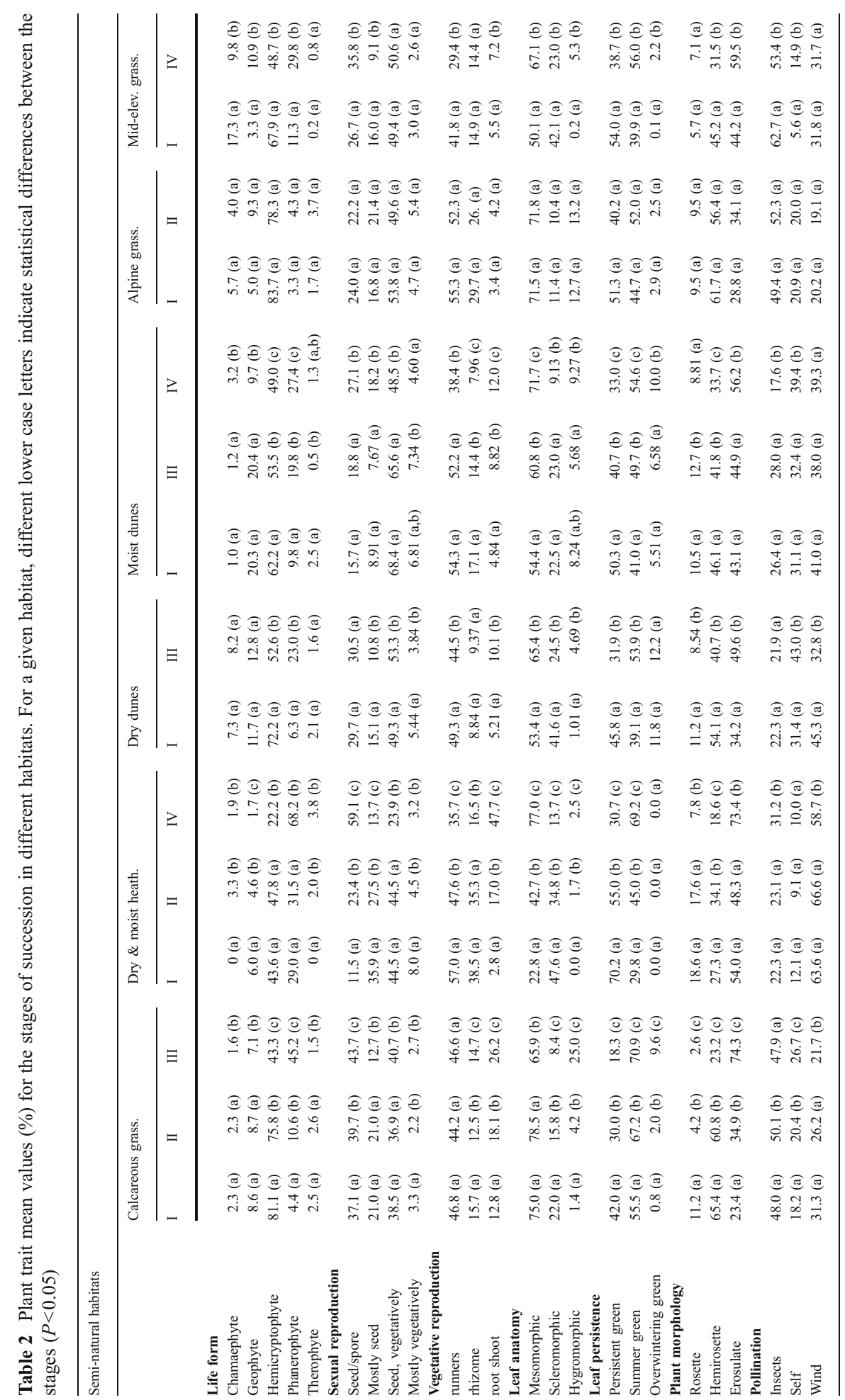


Table 2 (continued)

Arable fields

\begin{tabular}{|c|c|c|c|c|c|c|}
\hline & \multicolumn{4}{|c|}{ Arable fields (1) } & \multicolumn{2}{|c|}{ Arable fields (2) } \\
\hline & $\mathrm{I}$ & II & III & IV & I & II \\
\hline \multicolumn{7}{|l|}{ Life form } \\
\hline Chamaephyte & $0.5(\mathrm{a})$ & $2.1(\mathrm{~b})$ & $2.0(\mathrm{~b})$ & $1.3(\mathrm{c})$ & $1.4(\mathrm{a})$ & 1.7 (a) \\
\hline Geophyte & $6.8(a, b)$ & $6.9(b)$ & $8.5(\mathrm{a}, \mathrm{c})$ & $8.3(\mathrm{a}, \mathrm{c})$ & 5.4 (a) & $10.8(b)$ \\
\hline Hemicryptophyte & 48.8 (a) & $60.6(b)$ & $57.2(\mathrm{c})$ & $43.4(a)$ & 49.7 (a) & 54.9 (b) \\
\hline Phanerophyte & $9.4(\mathrm{a})$ & 12.7 (a) & $25.6(b)$ & $41.3(\mathrm{c})$ & 11.3 (a) & $25.4(b)$ \\
\hline Therophyte & 33.9 (a) & $16.4(b)$ & $4.5(\mathrm{c})$ & $1.8(\mathrm{~d})$ & 32.3 (a) & $6.1(\mathrm{~b})$ \\
\hline \multicolumn{7}{|l|}{ Sexual reproduction } \\
\hline Seed/spore & $65.4(a)$ & 49.1 (b) & $37.4(\mathrm{c})$ & $40.4(d)$ & $71.2(\mathrm{a})$ & 41.0 (b) \\
\hline Mostly seed & $6.5(\mathrm{a})$ & $8.3(a, b)$ & $9.5(\mathrm{~b}, \mathrm{c})$ & $11.7(\mathrm{c})$ & 3.9 (a) & $8.7(b)$ \\
\hline Seed, vegetatively & 25.5 (a) & 40.4 (b) & $51.0(\mathrm{c})$ & $45.9(\mathrm{~d})$ & 22.2 (a) & 46.4 (b) \\
\hline Mostly vegetatively & $0.8(\mathrm{a}, \mathrm{b})$ & $0.8(b)$ & $0.8(b)$ & $0.3(a)$ & $1.4(a)$ & $3.8(b)$ \\
\hline \multicolumn{7}{|c|}{ Vegetative reproduction } \\
\hline runners & $16.2(a)$ & $27.2(b)$ & $36.0(\mathrm{c})$ & $34.6(\mathrm{c})$ & 12.7 (a) & 33.6 (b) \\
\hline rhizome & $2.5(\mathrm{a})$ & $4.7(b, c)$ & $4.5(b)$ & $5.9(\mathrm{c})$ & 0.4 (a) & $6.5(b)$ \\
\hline root shoot & $5.6(a)$ & $9.0(b)$ & $13.0(\mathrm{c})$ & $15.7(d)$ & 6.9 (a) & 7.6 (a) \\
\hline \multicolumn{7}{|l|}{ Leaf anatomy } \\
\hline Mesomorphic & 65.5 (a) & $70.0(b)$ & $71.0(b, c)$ & 71.9 (c) & 70.4 (a) & 70.7 (a) \\
\hline Scleromorphic & $12.3(\mathrm{a})$ & $11.2(\mathrm{a}, \mathrm{b})$ & $11.0(\mathrm{a}, \mathrm{b})$ & $10.1(b)$ & 17.2 (a) & 17.9 (a) \\
\hline Hygromorphic & $13.8(a)$ & $10.4(b)$ & 9.9 (b) & $12.4(\mathrm{a})$ & 9.6 (a) & 8.4 (a) \\
\hline \multicolumn{7}{|l|}{ Leaf persistence } \\
\hline Persistent green & $19.7(a)$, & 30.9 (b) & 25.9 (a) & $15.6(\mathrm{c})$ & 23.7 (a) & 23.7 (a) \\
\hline Summer green & 47.7 (a) & 48.7 (a) & $66.2(b)$ & $78.6(\mathrm{c})$ & 47.8 (a) & $67.0(\mathrm{~b})$ \\
\hline Overwintering green & 32.1 (a) & $18.2(b)$ & 4.9 (c) & $2.7(d)$ & 28.5 (a) & 9.3 (b) \\
\hline \multicolumn{7}{|l|}{ Plant morphology } \\
\hline Rosette & 46.1 (a) & 40.9 (a) & $52.6(\mathrm{~b})$ & 67.1 (c) & 4.6 (a) & 3.6 (a) \\
\hline Hemirosette & $46.8(a, b)$ & $52.4(\mathrm{a})$ & 41.3 (b) & $27.8(\mathrm{c})$ & $54.3(\mathrm{a})$ & 44.3 (a) \\
\hline Erosulate & $6.6(a)$ & 5.5 (a) & 4.8 (a) & $3.4(b)$ & 41.1 (a) & $52.0(\mathrm{~b})$ \\
\hline \multicolumn{7}{|l|}{ Pollination } \\
\hline Insects & $52.6(a)$ & $44.5(b)$ & $39.5(c)$ & $36.2(\mathrm{~d})$ & 34.5 (a) & 34.4 (a) \\
\hline Self & $32.8(a)$ & 39.4 (b) & $42.3(b)$ & 39.9 (b) & $49.0(\mathrm{a})$ & 40.7 (a) \\
\hline Wind & $11.1(\mathrm{a}, \mathrm{b})$ & 12.4 (a) & 14.9 (b) & 19.7 (c) & 16.5 (a) & $29.0(b)$ \\
\hline
\end{tabular}

generally decreased with succession in semi-natural habitats, whereas it decreased in arable fields. In contrast, the proportion of plants pollinated by insects decreased or remained stable in arable fields and showed a variable response in semi-natural habitats. Finally, self-pollination exhibited a more varied response depending on habitat type. 


\section{Succession and Changes in Plant Functional Traits}

Results of PCA show that on its positive segment the first axis gathered plants with persistent, scleromorphic leaves, "runner" or "rhizome" types for vegetative reproduction, seeds as main type for sexual reproduction and pollinated by wind. In contrast, the negative segment of the first axis gathered plants with mesomorphic overwintering leaves, reproduction by seeds exclusively, and high Ellenberg values for soil reaction and nitrogen availability (Fig. 5a). This axis thus reflected a trophic gradient and a gradient of "naturalness" (land-use intensity), as it clearly separated the formerly extensively used, nutrient-poor heathlands from the intensively used, nutrient-rich arable fields. The second axis separated plants dominated by hemirosette morphology, hemicryptophyte form, ruderals and high Ellenberg light values (positive segment, Fig. 5a) from plants characterized mainly (negative segment) by an erosulate morphology, phanerophyte form, "root-shoot" vegetative reproduction, summer green leaves and competitors according to Grime's classification. Therefore, this second axis was linked to vegetation dynamics from open to woody stages, as it opposed the initial stages against the later, more mature stages.

Successional pathways taken as a whole were parallel for all semi-natural habitats along a direction from the top right to the bottom left corner (Fig. 5b), i.e., from an open to a more woody and nutrient-demanding vegetation. Pathways of arable fields showed a contrasting pattern, following a direction from the top left to the bottom left corner.

\section{Discussion}

\section{Methodological Constraints}

This study combined vegetation data from habitats largely differing in soil, climate and land-use history. Furthermore, the methods used to collect basic data differed considerably among studies. An important constraint is that we merged permanent and non-permanent plot studies that by nature provide information at different temporal and spatial scales. Nevertheless, both approaches provide information on the main patterns in the structure and dynamics of the development of the vegetation. The main criticism on the use of space-for-time substitution or chronosequencing is the assumption that each site in the chronosequence differs only in age and has experienced the same history in its biotic and abiotic components (Glenn-Lewin and van der Maarel 1992; Johnson and Miyanishi 2008). Although this is not always true, chronosequences provide a valuable approach for inferring many aspects of successional change (Foster and Tilman 2000). To handle the issues of combining permanent and non-permanent plots, we first divided the succession into stages based on physiognomy so that permanent and non-permanent plots provided a comparable level of information. Second, we tried to minimize the limitations associated with chronosequences (see Pickett 1989) by studying succession for each habitat on rather limited areas having comparable ecological characteristics, i.e., the same climatic and edaphic conditions and, to a large extent, similar history. With such precautions, permanent plots and chronosequences are comparable (Bakker et 
Fig. 5 Results of the PCA analysis. a Projection of the trait values in the correlation circle; trait values whose contributions are 1.5 times higher than the mean contribution are in boldface for axis 1 and in italics for axis 2. Axis 1: explained variance $=38 \%$; Axis 2: explained variance $=20 \%$. LP - Leaf persistence, LA - Leaf anatomy, VP - Vegetative propagation, RLF - Raunkiaer life form, Reproduction-S - Reproduction by seed/spore; Reproduction-ssv - Reproduction mostly by seed and rarely vegetative, Reproduction-vvs - Reproduction mostly vegetative, rarely by seed, Ellenberg-L - Indicator value for light availability, Ellenberg-R - Indicator value for soil reaction, Ellenberg-N - Indicator value for nitrogen availability, Ellenberg-F - Indicator value for soil moisture (see also Material and Methods, some of the variable with minor importance are not labelled). b Projection of the stages for the different habitats in the factorial plane. Subsequent stages are connected for each habitat (solid lines: arable fields, dashed lines: semi-natural habitats)

al. 1996). A second constraint was the differences in protocols used to collect vegetation data like the number and size of plots. The use of different plot sizes which is currently observed in most studies like ours gathering many relevés made by different authors at different times - can generate problems in vegetation patterns analysis (e.g., Otýpková and Chytrý 2006; Dengler et al. 2009). However, the use of different plot sizes to study successional changes is a function of the system studied. Smaller plots were used to sample vegetation in open habitats and larger ones are necessary to sample the woody vegetation (Chytrý and Otýpková 2003). To minimize the influence of variations of plot size, we have chosen to analyze the data at the stage level instead at the more variable plot level. Moreover it must be noted that plot size has often no influence on patterns of vegetation composition: Otýpková and Chytrý (2006) showed that patterns resulting from the ordination analyses of vegetation data patterns were not affected by large fluctuations of plot size, particularly in the analysis of heterogeneous vegetation types.

The use of plant functional traits allowed us to perform a global analysis combining habitats to detect general trends (Díaz et al. 2001). Nevertheless, the results can be influenced by the way plant traits are computed. We only used presence/absence of species and therefore we considered a first-level filtering process: species have a certain probability of being present or not (occurrence). This approach ignores a second-level filtering process that considers the probability of becoming dominant in cover abundance. We acknowledge that these two different ways of analyzing a trait-environment relationship do not always lead to similar results (Cingolani et al. 2007).

\section{Species Composition and Richness: Profound Changes Due to Abandonment and Woody Colonization}

As expected, land abandonment and subsequent colonization by woody species were associated with changes in floristic composition in all habitats studied. High species turnover has frequently been described after land abandonment through the different stages of succession, in particular when woody colonization has occurred (see for instance Harmer et al. 2001).

Initially species-rich, semi-natural habitats were more strongly affected by land abandonment, as illustrated with calcareous grasslands that showed a strong decrease in plant richness. This is in agreement with previous studies emphasizing the importance of land abandonment as a major cause for plant diversity decline. 

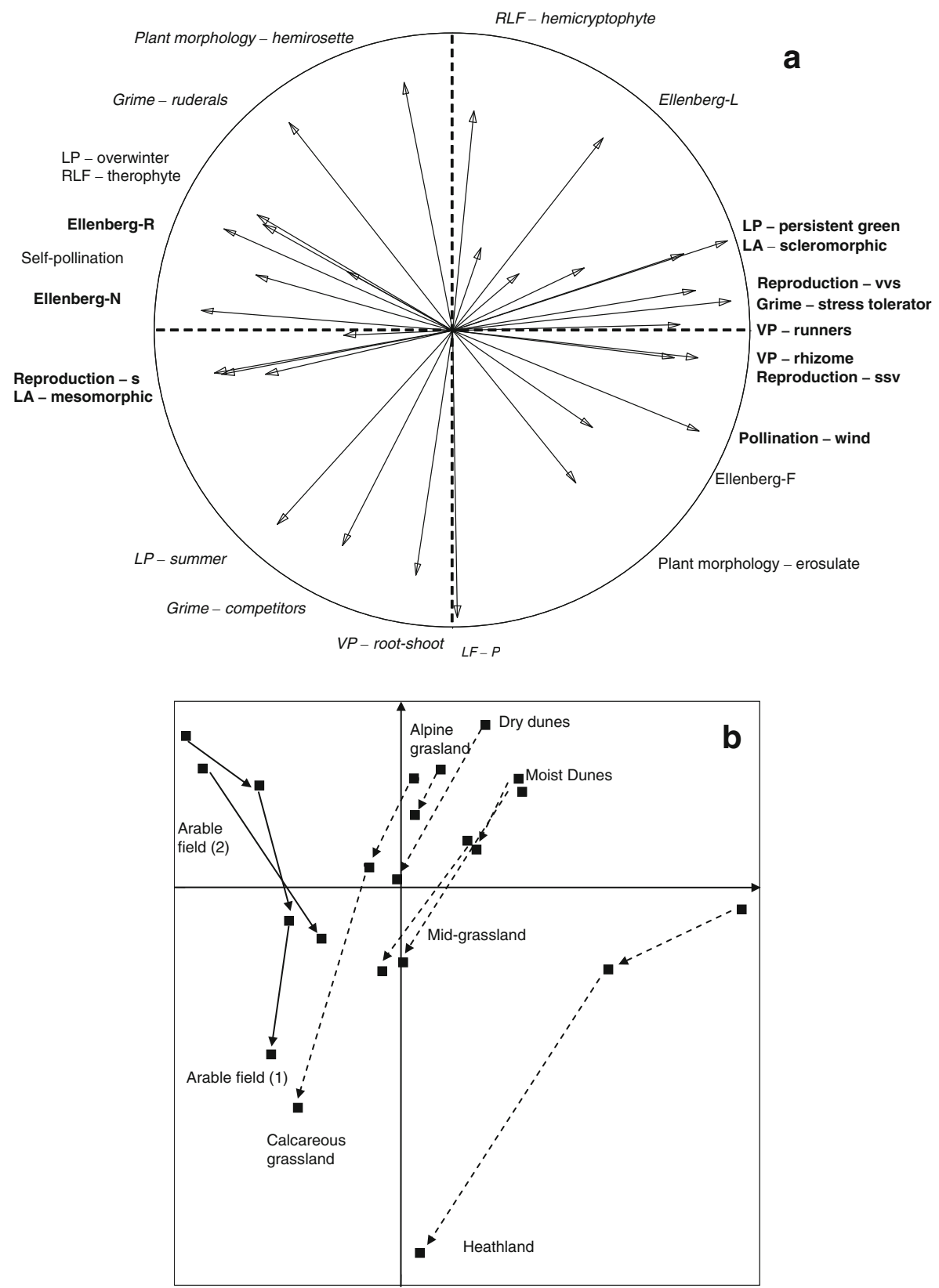

Cessation of traditional management practices (grazing, mowing) can lead to the accumulation of litter, which impedes seed germination and the establishment of seedlings (Foster and Gross 1997; Tilman 1997; Pärtel et al. 2005). The decrease in species richness in open meadow is also due to the increasing importance of nitrophilous, tall herbs and grasses that benefit from the increased nutrient availability after grazing abandonment (Krahulec et al. 2001). In contrast, in habitats 
of low initial species richness (heathland, coastal grassland), the extinction of initialstage species was counterbalanced by colonization by new species during later stages of succession leading to a stable trajectory of species richness in these habitats. Finally, the increase in species richness in mid-elevation grasslands may be explained by the high light availability in woody stages composed of birch or Scots pine facilitating the coexistence of semi-shade-tolerant species as well as heathland species (Prévosto 1999; Curt et al. 2003). Similarly, in arable field (1), the peak of species richness at mid- stages of succession before tree canopy closure was also due to the coexistence of different life forms and dispersal strategies (Harmer et al. 2001; Bonet and Pausas 2004; Dölle et al. 2008). In contrast, the decline of species richness in arable field (2) may be explained by the establishment of highly competitive non-woody species, which also prevented tree or shrub encroachment. Consequently, the idiosyncratic trajectories of species appear to be influenced by the species pool with its functional traits as well as local habitat conditions.

\section{Species of the Red Lists: a Marked Decline in Semi-Natural Habitats}

Semi-natural habitats were characterized by a major loss of biodiversity, highlighting the need for conservation of habitats with low-intensity land use (former agropastoral land use or some type of suitable replacement management practice), as already indicated by Provoost et al. (2004) for dry coastal dune grasslands. The increase in tree and shrub cover due to either natural regeneration or afforestation is recognized as one of the main threats to rare grassland species (Provoost et al. 2004; Pykäla et al. 2005).

By contrast, the low number of species on the Red Lists in arable fields may be explained by the rapid colonization of these habitats by perennial and woody plants, by the composition of the soil seed bank and by specific soil characteristics leaving little opportunity for patrimonial species to establish.

\section{Plant Indicator Values and Plant Trait Changes with Succession: Similarities and Differences}

The ecosystems studied here showed various succession pathways after land abandonment. Despite this variability, our results suggest that changes in plant traits and indicator values followed a similar general pattern (Fig. 5).

\section{Similarities in Indicator and Trait Value Changes with Succession}

Some plant trait changes are closely associated with response to vegetation dynamics following land abandonment, whatever the type of habitat. An obvious illustration is the expected increase in phanerophytes with succession due to tree or shrub establishment (e.g., Grime 1979; McIntyre et al. 1995; Bernhardt-Römermann et al. 2008). We also found a consistent response of leaf anatomy and persistence with succession as a result of shading conditions in late succession stages, in contrast to the full-light conditions of the initial stages.

Similarities can also be found in the changes in Ellenberg's and Grime's indicator values. Ellenberg values for light decreased during succession for all habitats, thus 
quantifying the canopy closure by shrubs or trees that leads to a decrease in heliophilous plants and to an increase of semi-shade- and shade-tolerant species (Dölle et al. 2008).

Analysis of plant-strategy types according to Grime's CSR classification showed an increase in competitors and a decrease in ruderal species during succession in all the habitats. These changes were related to the decrease of disturbances after land abandonment, as disturbances are known to favour short-lifespan plants that reproduce rapidly, such as ruderals (e.g., Grime 1979; Noy-Meir 1995; Huisman et al. 1999).

\section{Differences Between Semi-Natural Habitats and Arable Fields}

Arable fields differed from semi-natural habitats by the relative importance of therophytes (mainly weeds). Reproductive strategies also differed between these two types of habitat: semi-natural habitats initially harboured more species reproducing vegetatively than arable fields. Vegetative reproduction may be an advantage for long-term persistence in undisturbed or moderately disturbed sites (Noble and Slatyer 1980; McIntyre et al. 1995). After land abandonment, species reproducing by seeds increased only in grazed sites and decreased in arable sites. Arable fields generally benefited from greater nutrient availability, thus sharpening competition in the course of succession. This would likely promote a strategy of vegetative reproduction favouring local spreading and devoting more resources to competing with neighbours (Bernhardt-Römermann et al. 2008; Dölle et al. 2008). This argument could also explain why runner species increased in arable fields but decreased in the semi-natural habitat succession.

Plant architecture plays an important role in the response of herbaceous species to disturbance (Lavorel et al. 1999; Römermann et al. 2009). Taxa that tend to have a basal position of leaves (rosette, hemi-rosette) are favoured by grazing and so regress in semi-natural habitats after land abandonment but progress in arable fields. In contrast, species characterized by leaves that are evenly spaced along the stem (erosulate) are generally grazing-intolerant (Dupré and Diekmann 2001) and therefore increase after land abandonment in semi-natural habitats.

The decrease in the importance of wind pollination with succession in seminatural habitats was fully expected, given the shift from an initial open landscape to a closed woody landscape in which conditions are less favourable for wind pollination but better geared to self-pollination or insect pollinators (Culley et al. 2002). Arable fields exhibited a different response, but this difference from the seminatural habitats may not be of great significance, as wind pollination is a minor process and is also affected by phylogeny (annual species are generally mostly selfpollinating (Aarssen 2000)).

Ellenberg and Grime's indicator values also showed contrasting responses depending on type of habitat. The increase in Ellenberg values for nitrogen, noted only for semi-natural habitats, can be explained by litter accumulation and subsequent mineralization, as well as by possible changes in mass and species composition of the soil biota after land abandonment (Archer et al. 2001; Ehrenfeld 2003). In contrast, decreasing N-Ellenberg values through the consecutive stages of succession in arable fields reflect the decrease in nutrient availability due to 
cessation of the application of fertilizer or manure and subsequent natural soil acidification processes (Glatzel 1991).

Stress-tolerators sharply declined in semi-natural habitats but not in arable fields, highlighting the more intense competition regime in the arable habitats due to greater nutrient availability.

\section{Variations in Plant Traits Among the Semi-Natural Habitats}

As shown in Fig. 5b, semi-natural habitats show large variations among successional pathways, although the pathways are all oriented along the same direction. This result is the consequence of major differences in environmental factors and communities in these habitats. A clear illustration is given by successional pathway of heathlands, which differs strongly from the other semi-natural habitat pathways. Heathland vegetation actually shows more wind-dispersed species with scleromorphic persistent green leaves and phanerophytes than the other semi-natural habitats. These specificities reflect the impacts of specific disturbance regimes (extensive grazing) and specific environmental factors (particularly soils characterized by marked acidity and low fertility, as reflected by the corresponding mean Ellenberg indicator values).

\section{Conclusion}

Our study showed that succession occurred along a broadly predictable pathway, all habitats sharing a common set of plant traits and indicator values. The importance of landuse legacies is also highlighted, as we found some contrasting responses of the vegetation to land abandonment between initially semi-natural habitats - despite harbouring various ecosystems - and initially arable habitats. These differences in traits of plant species and their changes through succession reflect fundamentally different successional drivers between arable fields and semi-natural habitats. The vegetation assembly of most of the open semi-natural habitats is the result of a long co-evolution of plants and grazers leading to a set of plant species that can sustain ecological conditions of life in open areas subjected to regular disturbances (Zobel 1992). In contrast, the species pool of formerly arable lands was shaped by other types of disturbance and was deeply influenced by the nature and frequency of the agricultural management practices.

Acknowledgements This work was supported by ALTER-Net (A Long-term Biodiversity, Ecosystem and Awareness Research Network), a Network of Excellence funded under the 6th Framework Programme of the European Commission (www.alter-net.info).

Open Access This article is distributed under the terms of the Creative Commons Attribution Noncommercial License which permits any noncommercial use, distribution, and reproduction in any medium, provided the original author(s) and source are credited.

\section{References}

Aarssen LW (2000) Why are most selfers annuals? A new hypothesis for the fitness benefit of selfing. Oikos 89:606-612 
Archer S, Boutton TW, Hibbard KA (2001) Trees in grasslands: biogeochemical consequences of woody plant expansion. In Schulze E-D, Harrison SP, Heimann M, Holland EA, Lloyd J, Prentice IC, Schimel D (eds) Global biogeochemical cycles in the climate system. Academic Press, San Diego, pp 115-130

Bakker JP (1989) Nature management by grazing and cutting. On the ecological significance of grazing and cutting regimes applied to restore former species-rich grassland communities in the Netherlands. Kluwer Academic Press, Dordrecht

Bakker JP, Olff H, Willems JH, Zobel M (1996) Why do we need permanent plots in the study of longterm vegetation dynamics? J Veg Sci 7:147-155

Bernhardt-Römermann M, Römermann C, Nuske R, Parth A, Klotz S, Schmidt W, Stadler J (2008) On the identification of the most suitable traits for plant functional trait analyses. Oikos 117:1533-1541

Biesbrouck B, Es K, Van Landuyt W, Vanhecke L, Hermy M, Van den Bremt P (2001) Een ecologisch register voor hogere planten als instrument voor het natuurbehoud in Vlaanderen (An ecological register of vascular plants as a tool for nature conservation in Flanders). Flo.Wer vzw, Instituut voor Natuurbehoud (IN), Katholieke Universiteit Leuven (KUL), Nationale Plantentuin van België, Brussels

Bignall DM, McCracken DI (1996) Low-intensity farming systems in the conservation of the countryside. $J$ Appl Ecol 33:413-424

Bonet A, Pausas JG (2004) Species richness and cover along a 60-year chronosequence in old fields of southeastern Spain. Pl Ecol 174:257-270

Bossuyt B, Butaye J, Honnay O (2006) Seed bank composition of open and overgrown calcareous grassland soils - a case study from Southern Belgium. J Environm Managem 79:364-371

Chytrý M, Otýpková Z (2003) Plot sizes used for phytosociological sampling of European vegetation. $J$ Veg Sci 14:563-570

Cingolani AM, Cabido M, Gurvich DE, Renison D, Díaz S (2007) Filtering processes in the assembly of plant communities: Are species presence and abundance driven by the same traits? J Veg Sci 18:911-920

Coquillard P (1993) Dynamique des systèmes agro-pastoraux de l'étage montagnard du Massif du Sancy et de la Chaîne des Puys: variations biologiques et fonctionnelles; exemple d'application au modèle à Calluna vulgaris (L.) Hull. Thèse Univ. Aix-Marseille, Marseille

Cramer VA, Hobbs RJ, Standish RJ (2008) What's new about old fields? Land abandonment and ecosystem assembly. Trends Ecol Evol 23:104-112

Culley TM, Weller SG, Sakai AK (2002) The evolution of wind pollination in angiosperms. Trends Ecol Evol 17:361-369

Curt T, Prévosto B, Klesczewski M, Lepart J (2003) Post-grazing Scots pine colonization of mid-elevation heathlands: population structure, impact on vegetation composition and diversity. Ann Forest Sci 60:711-724

Dengler J, Löbel S, Dolnik C (2009) Species constancy depends on plot size - a problem for vegetation classification and how it can be solved. J Veg Sci 20:754-766

Díaz S, Noy-Meir I, Cabido M (2001) Can grazing response of herbaceous plants be predicted from simple vegetation traits? J Appl Ecol 38:497-508

Dupré C, Diekmann M (2001) Differences in species richness and life-history traits between grazed and abandoned grasslands in southern Sweden. Ecography 24:275-286

Dölle M, Bernhardt-Römermann M, Parth A, Schmidt W (2008) Changes in life history trait composition during undisturbed old-field succession. Flora 203:508-522

Dzwonko Z (2001) Assessment of light and soil conditions in ancient and recent woodlands by Ellenberg indicator values. J Appl Ecol 38:942-951

Dzwonko Z, Loster S (1997) Effects of dominant trees and anthropogenic disturbances on species richness and floristic composition of secondary communities in southern Poland. J Appl Ecol 34:861-870

Ehrenfeld JG (2003) Effects of exotic plant invasions on soil nutrient cycling processes. Ecosystems 6:503-523

Ellenberg H, Weber HE, Düll R, Wirth V, Werner W, Paulissen D (2001) Zeigerwerte von Pflanzen in Mitteleuropa. 3rd Edition. Scripta Geobot 18:3-258

Foster BL, Gross KL (1997) Partitioning the effects of plant biomass and litter on Andropogon gerardi in old-field vegetation. Ecology 78:2091-2104

Foster BL, Tilman D (2000) Dynamics and static views of succession: Testing the descriptive power of the chronosequence approach. Pl Ecol 146:1-10

Garve E (2004) Rote Liste und Florenliste der Farn- und Blütenpflanzen in Niedersachsen und Bremen. Informationsdienst Naturschutz Niedersachsen 24, Niedersächsisches Landesamt für Ökologie, Hannover

Glatzel G (1991) The impact of historic land use and modern forestry on nutrient relations of Central European forest ecosystems. Fertilizer Res 27:1-8 
Glenn-Lewin DC, van der Maarel E (1992) Patterns and processes of vegetation dynamics. In GlennLewin DC, Peet RK, Veblen TT (eds) Plant succession theory and prediction. Chapman \& Hall, London, pp 11-59

Grime JP (1977) Evidence for the existence of three primary strategies in plants and its relevance to ecological and evolutionary theory. Amer Naturalist 111:1169-1194

Grime JP (1979) Plant strategies and vegetation processes. Wiley \& Sons, Chichester

Grubb JP (1977) The maintenance of species-richness in plant communities: the importance of the regeneration niche. Biol Rev 52:107-145

Gustavsson E, Lennartsson T, Emanuelsson M (2007) Land use more than 200 years ago explains current grassland diversity in a Swedish agricultural landscape. Biol Conservation 138:47-59

Harmer R, Peterken G, Kerr G, Poulton P (2001) Vegetation changes during 100 years of development of two secondary woodlands on abandoned arable land. Biol Conservation 101:291-304

Hill MO, Roy DB, Thompson K (2002) Hemeroby, urbanity and ruderality: bioindicators of disturbance and human impact. J Appl Ecol 39:708-720

Huisman J, Grover JP, van der Wal R, van Andel J (1999) Competition for light, plant-species replacement and herbivore abundance along productivity gradients. In Olff $\mathrm{H}$, Brown VK, Drent $\mathrm{RH}$ (eds) Herbivores: between plants and predators. Blackwell Science, Oxford, pp 239-270

Huston M (1979) A general hypothesis of species diversity. Amer Naturalist 113:81-101

Jäger EJ, Werner K (2002) Rothmaler - Exkursionsflora von Deutschland, Kritischer Band 4. Spektrum, Heidelberg

Johnson EA, Miyanishi K (2008) Testing the assumptions of chronosequences in succession. Ecol Lett 11:419-431

Klotz S, Kühn I, Durka W (2002) BIOFLOR Eine Datenbank mit biologisch-ökologischen Merkmalen zur Flora von Deutschland. Schriftenreihe Vegetationsk 38:1-334

Krahulec F, Skálová H, Herben T, Hadincová V, Wildová R, Pecháčková S (2001) Vegetation changes following sheep grazing in abandoned mountain meadows. Appl Veg Sci 4:97-102

Lavorel S, Garnier E (2002) Predicting changes in community composition and ecosystem functioning from plant traits - revisiting the Holy Grail. Funct Ecol 16:545-556

Lavorel S, Rochette C, Lebreton J-D (1999) Functional groups for response to disturbance in Mediterranean old fields. Oikos 84:480-498

Lavorel S, Diaz S, Cornelissen JHC, Garnier E, Harrison SP, McIntyre S, Pausas JG, Pérez-Harguindeguy N, Roumet C, Urcelay C (2007) Plant functional types: Are we getting closer to the holy grail? In Canadell JG, Pataki D, Pitelka L (eds) Terrestrial ecosystems in a changing world. The IGBP Series, Springer-Verlag, Berlin, Heidelberg, pp 149-160

McIntyre S, Lavorel S, Tremont RM (1995) Plant life-history attributes: their relationship to disturbance response in herbaceous vegetation. $J$ Ecol 83:31-44

Niklfeld H, Schratt-Ehrendorfer L (1999) Rote Listen gefährdeter Farn- und Blütenpflanzen (Pteridophyta und Spermatophyta) Österreichs (2. Fassung). In Niklfeld H (ed) Rote Listen gefährdeter Pflanzen Österreichs. Ed. 2. Grüne Reihe des Bundesministeriums für Umwelt, Jugend und Familie 10, Austria Medienservice GmbH, Graz, pp 33-151

Noble IR, Slatyer RO (1980) The use of vital attributes to predict successional changes in plant communities subject to recurrent disturbances. Vegetatio 43:5-21

Noy-Meir I (1995) Interactive effects of fire and grazing on structure and diversity of Mediterranean grasslands. J Veg Sci 6:701-710

Olivier L, Galland JP, Maurin H (1995) Livre Rouge de la flore menacée de France, Tome I, espèces prioritaires. Collection Patrimoines Naturels n²0, SPN-IEGB/MNHN, Ministère de 1'Environnement, CBN Porquerolles, Paris

Otýpková Z, Chytrý M (2006) Effects of plot size on the ordination of vegetation samples $J$ Veg Sci $17: 465-472$

Pärtel M, Bruun H, Sammul M (2005) Biodiversity in temperate European grasslands: origin and conservation. In Lillak R, Viirat R, Linke A, Geherman V (eds) Integrating grassland farming and biodiversity. Proceedings of the 13th International Symposium of the European Grassland Federation, Tartu, pp 1-14

Peco B, Sánchez AM, Azcárate FM (2006) Abandonment in grazing systems: Consequences for vegetation and soil. Agric Ecosyst Environm 113:284-294

Persson S (1980) Succession in a south-Swedish deciduous wood: a numerical approach. Vegetatio 75:143-152

Pettit NE, Froend RH, Ladd PG (1995) Grazing in remnant woodland vegetation: changes in species composition and life form groups. J Veg Sci 6:121-130

Pickett STA (1989) Space-for-time substitution as an alternative to long term studies. In Likens GE (ed) Long-term studies in ecology. Springer-Verlag, New York, pp 110-135 
Poschlod P, Bakker JP, Kahmen S (2005) Changing land use and its impact on biodiversity. Basic Appl Ecol 6:93-98

Prévosto B (1999) Analyse fonctionnelle des boisements spontanés et modélisation de leur développement. Application aux peuplements de Betula pendula (Roth.) et Pinus sylvestris (L.) en moyenne montagne volcanique (la Chaîne des Puys, Massif Central). Thèse Univ. Aix-Marseille, Marseille

Provoost S, Ampe C, Bonte D, Cosyns E, Hoffmann M (2004) Ecology, management and monitoring of dune grassland in Flanders, Belgium. $J$ Coastal Conservation 22:33-42

Pykäla J (2000) Mitigating human effects on European biodiversity through traditional animal husbandry. Conservation Biol 14:705-712

Pykäla J, Luoto M, Heikkinen RK, Kontula T (2005) Plant species richness and persistence of rare plants in abandoned semi-natural grasslands in northern Europe. Basic Appl Ecol 6:25-33

Römermann C, Bernhardt-Römermann M, Kleyer M, Poschlod P (2009) Substitutes for grazing in seminatural grasslands - do mowing or mulching represent valuable alternatives to maintain vegetation structure? J Veg Sci 20:1086-1098

Schaffers AP, Sýkora K (2000) Reliability of Ellenberg indicator values for moisture, nitrogen and soil reaction: a comparison with field measurements. J Veg Sci 11:225-244

Schmidt W (1993) Sukzession und Sukzessionslenkung auf Brachäckern - Neue Ergebnisse aus einem Dauerflächenversuch. Scripta Geobot 20:65-104

Schmidt W (2006) Biodiversity and plant productivity in a grassland succession: effects of nutrient levels and disturbance regimes. Polish Bot Studies 22:437-448

Smith RS Rushton SP (1994) The effects of grazing management on the vegetation of mesotrophic (meadow) grassland in northern England. $J$ Appl Ecol 31:13-24

Stadler J, Trefflich A, Brandl R, Klotz S (2007) Spontaneous regeneration of dry grasslands on set-aside fields. Biodivers Conservation 16:621-630

Stoate C, Baldi A, Beja P, Boatman ND, Herzon I, van Doorn A, de Snoo GR, Rakosy L, Ramwell CE (2009) Ecological impacts of early 21 st century agricultural change in Europe - a review. J Environm Managem 91:22-46

Thioulouse J, Chessel D, Dolédec S, Olivier JM (1997) ADE-4: a multivariate analysis and graphical display software. Stat Computing 7:75-83

Tilman D (1997) Community invisibility, recruitment limitation, and grassland biodiversity. Ecology 78:81-92

van der Maarel E (1993) Relations between sociological-ecological species groups and Ellenberg indicator values. Phytocoenologia 23:343-362

van der Meijden R, Odé B, Groen CLG, Witte JPM, Bal D (2000) Bedreigde en kwetsbare vaatplanten in Nederland. Basisrapport met voorstel voor de Rode lijst (Endangered and vulnerable vascular plants in the Netherlands. Background report with proposal for a Red List). Gorteria 26:85-208

Young J, Watt A, Nowicki P, Alard D, Clitherow J, Henle K, Johnson R, Laczko E, McCracken D, Matouch S, Niemela J, Richards C (2005) Towards sustainable land use: identifying and managing the conflicts between human activities and biodiversity conservation in Europe. Biodiv Conservation 14: $1641-1661$

Zobel M (1992) Plant species coexistence: the role of historical, evolutionary and ecological factors. Oikos 65:314-320

Received: 10 July 2009/Revised: 17 June 2010 / Accepted: 22 September 2010 /

Published online: 6 April 2011 